\title{
Sustainable Relocation in Rural Areas: An Investigation in Cukur Village, Turkey
}

\author{
Nese Dikmen ${ }^{1}$
}

\begin{abstract}
Understanding whether individuals are satisfied with their new residential environment is crucial for assessing the sustainability of relocation projects. In this study, the relocation project for the part of Cukur village, under the risk of disaster was investigated. It was aimed to determine the changes that occurred in the living conditions of the beneficiaries as a result of the relocation project, the satisfaction levels of the residents with their dwelling units, lots and the settlement, the reasons of their satisfaction/dissatisfaction and the positive and negative aspects of the relocation project. The data obtained in the survey are based on discussions with the project developers and on the field surveys carried out in the region. The positive aspects of the project are the relocation of the villagers who live under the risk of disaster to a safe area, protection of the social ties between the old settlement and the new settlement, provision of houses with better physical conditions than the old ones, and the fact that infrastructure works required for basic living activities were completed. The disadvantages of the project are the problems caused by the method of payment of the housing loan, the problems experienced as a result of the workmanship errors in the dwellings, noise and natural lighting problems, and the fact that the daily activities of the villagers are interrupted due to the lack of provision of service spaces. Proposals have been suggested to ensure sustainable relocation projects in rural areas.
\end{abstract}

Keywords: Sustainable relocation, resettlement, housing, satisfaction.

\section{Introduction}

Disasters caused by natural hazards may be tragic, destructive and costly, and may also pose serious threats to the infrastructure and sustainable development of the countries [1]. Prevention as against recovery has become a model for rational approach to disaster management [2]. Exposure to hazards is an essential element of disaster risk. Here, exposure means that people, infrastructure, production, wealth, natural resources, including environmental services, and other elements required for livelihoods and social well-being have the possibility to encounter the physical events and their possible negative effects [3]. Efforts for disaster risk reduction play an important role in reducing the vulnerability of people to the adverse effects of dangerous events. Disaster risk reduction is defined as "actions intended to reduce the number of people killed and / or the amount of economic damage caused by a natural disaster" by reference [4]. The only option to reduce disaster risk is resettlement when the risk of exposure to a community may not be mitigated by another measure. Resettlement works are development projects that involve compulsory relocation of people and productive activities [5]. Risks, costs and benefits in the relocation process are addressed not only in economic terms, but also in social terms together with the way of living [6]. Resettlement does not consist of providing a house only; it is a complex and multidimensional process that may lead to very negative 
consequences if it is not properly planned and executed. Practices to protect the lives and assets of those exposed to disaster risk shall not cause them to become more vulnerable to other social and economic risks [5]. The basic criterion for decisions to be made about the new settlements to be established shall be to ensure a sustainable relocation. According to reference [7], sustainability of a resettlement project should be determined by measuring satisfaction level of the relocated people with regards to their new living conditions.

Investigating resettlement projects that were implemented in the past and identifying the positive and negative aspects of these projects is important in terms of minimizing the problems that may arise in future implementations. Investigating the satisfaction and dissatisfaction levels of the beneficiaries is an effective way to identify the positive and negative aspects of the reconstruction projects. According to reference [8], if we learn the level of satisfaction of people with a product or service, it may be possible to improve that product or service to increase the level of satisfaction. Satisfaction is a function of how close is one to the expectation about something they have [9]. In recent years, the basic criterion for assessing environmental quality is satisfaction. Understanding whether individuals are satisfied with their residential environment is crucial for assessing the qualities of their life and whether the housing policies have achieved their goals [10]. Residential satisfaction, an essential factor for individuals on their preferences about houses, neighbourhood environment and facilities [11], also determines the way they respond to the residential environment. Understanding the factors that generate a response based on satisfaction or dissatisfaction may play a critical role in building successful housing policies [12]. The similarity of residential preferences to the characteristics of neighbourhood [13] as well as the level that their neighbourhoods meets the expectations of people affect the level of residential satisfaction [14]. The closer the present situation is to the expectations, the higher the level of satisfaction [15]. If the performance is better than expected, the level of satisfaction increases; while if it is worse, the level of satisfaction decreases [16]. Dissatisfaction usually results in moving or in alteration of the residence. When both options are not possible, this causes chronic dissatisfaction [17]. The socio-demographic characteristics of the residents, the characteristics of the houses, and the variables determining the socio-spatial characteristics of the neighbourhoods are the factors affecting residential satisfaction [14]. The physical characteristics of the houses have a considerable effect on the satisfaction of residents. This shows how important the residential unit plays a role, in determining the quality of the residential environment individually, and in determining the performance of the housing projects in general [18]. In addition to the neighbourhood facilities, the building properties such as the number of bedrooms, the size and location of the kitchen, and the quality of the materials are directly related to residential satisfaction [19]. Inadequacy of space results in dissatisfaction with home [20]. Housing planners shall know the performance of the buildings. Comparing the usage of a building to its design objectives may provide useful feedback for future design decisions. Because the buildings are complex and the assessment of the performance of the buildings includes a range of technical, functional, social and aesthetic considerations [19]. Understanding that home is an important type of space and place, and to consider it as a social, cultural and emotional structure without 
restricting it as a "dwelling" consisting solely of a physical structure allows us to combine the physical components with social, cultural and emotional components [21]. The usage level of residential environment may vary depending on how much time the residents spend at home and in the neighbourhood, and what they do in that time. Experience with daily activities at home affects residential satisfaction [10]. This is especially true for rural houses in Turkey; because as reference [22] points out a house in rural areas, where agricultural production is the fulcrum of the economy, is also a centre where agricultural activities are carried out. Most of the houses have two storeys and living spaces are available in the upper floors. The ground floor usually consists of service spaces [23]. In rural areas, the spatial organization of the houses is directly related to the daily activities of the residents [24]; and this shall be taken into account in housing projects produced for rural areas. In this study, the relocation project for the part of Cukur village, Isparta, under the risk of disaster was investigated. It was aimed that following questions are answered in the survey on a project where a new settlement consisting of 48 houses was built:

1. Why and how was a part of Cukur village relocated?

2. What changes have occurred in the living conditions of the beneficiaries after the relocation?

3. What is the level of satisfaction of the beneficiaries with their houses?

4. What are the reasons for the satisfaction/dissatisfaction of the beneficiaries with their houses?

5. What are the positive and negative aspects of the relocation project?

\section{The Materials and the Method}

In the first phase of the study, interviews were held with the authorities from the Isparta Provincial Disaster and Emergency Directorate of the Disaster and Emergency Management Presidency (AFAD) of the Prime Ministry of Republic of Turkey about the relocation project. In these interviews, information was obtained about why and how a part of Cukur village was relocated. The region was visited twice in spring 2017. In the course these field surveys, the headman of Cukur village was interviewed and information about the project process was taken from him. Photographs of the old and the new settlements were taken and a survey was conducted based on face-to-face interviews with the beneficiaries. Of the 48 houses built, 8 are used seasonally and 40 are used permanently. 1 resident, who is a beneficiary and who is over 18 years old, of the 40 houses that are being used continuously, is included in the sampling. The survey, in which 35 beneficiaries have participated, consists of two parts. In the first part, there are 10 questions about the physical characteristics of the previous houses of the residents, whether they have raised livestock before relocation, how long they have used their current house, whether they are raising livestock currently, whether they have made any changes on their houses and the aspects of their houses that they like or not. The second part is based on a 5-point likert scale and consists of questions about the satisfaction of the residents with their houses. The satisfaction levels of the residents with the houses are examined under three headings: dwelling unit, lot and settlement. Beneficiaries were asked to answer the questions asked under such headings with the following responses 
and clarify the reasons for their answers: I'm not satisfied at all (1), I'm not satisfied (2), fair enough (3), I'm satisfied (4) and I'm very satisfied (5). The questions based on residential satisfaction are specified in the table below (Table 1).

Table 1. Indicators of residents' satisfaction

\begin{tabular}{|c|c|c|c|c|c|}
\hline \multicolumn{4}{|c|}{ DWELLING UNIT } & \multirow{2}{*}{ LOT } & \multirow{2}{*}{ SETTLEMENT } \\
\hline SIZE & PLAN & FAÇADE & CONSTRUCTION & & \\
\hline $\begin{array}{l}\text { Number of } \\
\text { rooms }\end{array}$ & $\begin{array}{l}\text { Location of the sitting } \\
\text { room }\end{array}$ & $\begin{array}{l}\text { Number of the } \\
\text { windows }\end{array}$ & Building materials & Size & Location \\
\hline $\begin{array}{l}\text { Size of the } \\
\text { rooms }\end{array}$ & $\begin{array}{l}\text { Location of the living } \\
\text { room }\end{array}$ & $\begin{array}{l}\text { Dimensions of } \\
\text { the windows }\end{array}$ & $\begin{array}{l}\text { Construction } \\
\text { quality }\end{array}$ & Layout plan & $\begin{array}{l}\text { Distance to } \\
\text { field/garden }\end{array}$ \\
\hline $\begin{array}{l}\text { Size of the } \\
\text { terrace }\end{array}$ & $\begin{array}{l}\text { Location of the } \\
\text { bedroom }\end{array}$ & & & & Access \\
\hline $\begin{array}{l}\text { Size of the } \\
\text { house }\end{array}$ & $\begin{array}{l}\text { Location of the } \\
\text { kitchen } \\
\text { Location of the } \\
\text { bathroom } \\
\text { Location of the WC } \\
\text { Plan in general }\end{array}$ & & & & Infrastructure \\
\hline
\end{tabular}

\section{Project for Relocation of Cukur Village}

Isparta province is located in the Goller district to the north of the Mediterranean Region in Turkey. Cukur village is located on the east of Isparta and has a distance of $25 \mathrm{~km}$ to the city centre. The population of the village containing 165 houses is about 1400 people. In 2001, a piece of rock broken off from the hillside, where a part of the village leans against, caused the destruction of 1 house. In a geological survey conducted in 2007, it was determined that a part of the village is under the risk of rockfall disaster. In this survey, it was determined that improvement would not be possible due to the nature of the rocks and the inclination of the land. AFAD has decided to relocate the villagers living in the 48 houses in the risky area to a safe area. In Figure 1, a view of the village is seen. The marked area is the area at risk.

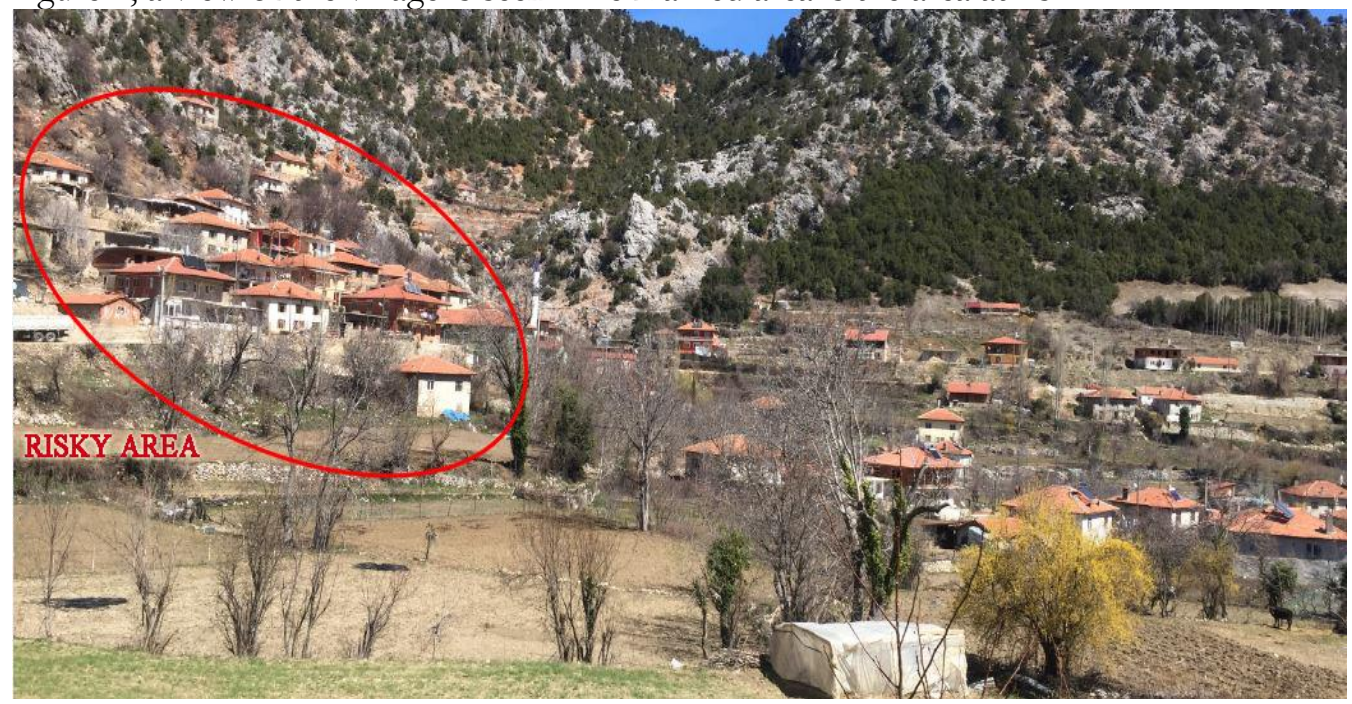

Figure 1. Cukur village, Isparta 
The Disaster and Emergency Management Presidency of the Prime Ministry of Republic of Turkey decided that the relocation project shall be performed by the EYY (Support for those who build their houses) method. EYY is a method where the state provides loans with convenient conditions to the beneficiaries for the construction of the houses, and where the beneficiaries are responsible for the management of the construction process. 20-year interest-free loans worth of 40,000 TL (approx. $€ 10,320$ ) were provided to the beneficiaries for the Cukur project. These loans were not paid as a lump sum. The authorities of Isparta Provincial Disaster and Emergency Directorate affiliated to AFAD inspected certain phases of the construction process, and the payments were made after these inspections. The Disaster and Emergency Management Presidency of the Prime Ministry of Republic of Turkey purchased a land located about $1 \mathrm{~km}$ away from the current settlement. The land size was divided into the number of the beneficiaries and each beneficiary has been given a lot with a size of $300 \mathrm{~m}^{2}$. As the lots were not big enough, it has been decided to construct attached houses. Isparta Provincial Disaster and Emergency Directorate has designed a single-storey reinforced concrete house with a size of $90 \mathrm{~m}^{2}$ for the Cukur project. The static project of this house was prepared in such a way as to enable to build another storey in the future. Beneficiaries were offered the option to have different designs made provided that they paid the price for such plans, but all the beneficiaries preferred to use the house plan designed by the Directorate. Figure 2 shows the plan of the house. Expropriation work required was completed in 2011. The construction process, which was started in 2012, was finished at the end of 2014. Houses were started to be used in early 2015. The construction process was completed in its due time, but the fact that the money deposited to a certain bank account by the Isparta Provincial Disaster and Emergency Directorate after the required inspections may be withdrawn both by the beneficiary and the contractor has occasionally caused some trouble. There have been cases where the money withdrawn by

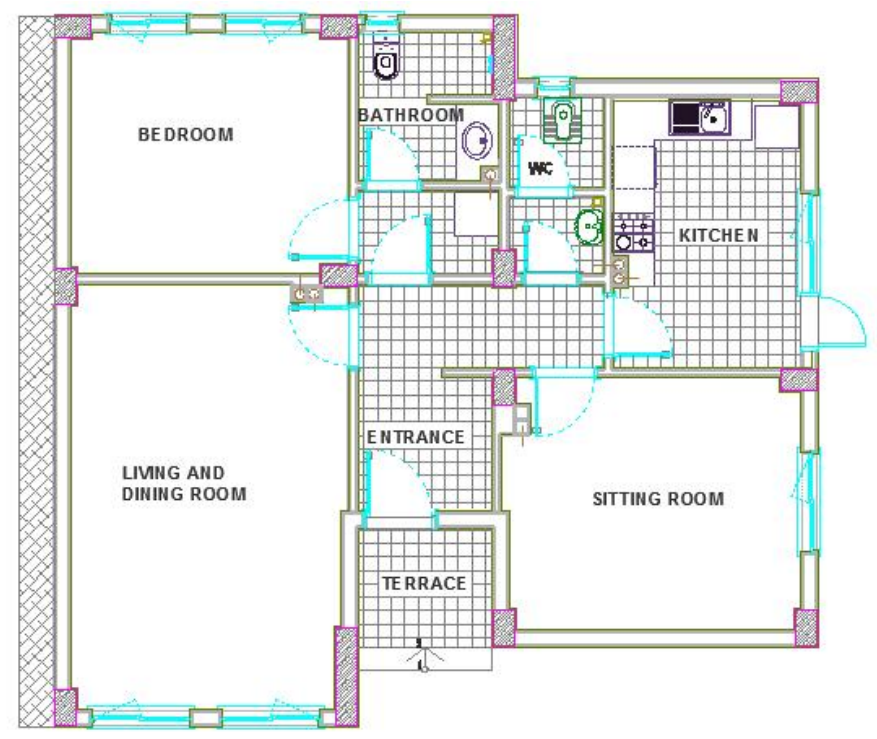
the beneficiary has not been paid in due time to the contractor.

Figure 2. Plan of the house 


\section{Results and Discussion}

\subsection{Changes That Occurred in the Living Conditions of the Villagers with the Relocation Project}

In the first part of the survey, beneficiaries were asked questions about their previous and current houses. The purpose of asking these questions is to determine what changes have occurred in the living conditions of the residents after they have moved to their new houses. The questions and answers received in this section are given below.

"Were you raising livestock before you moved here?" 28 of the beneficiaries replied "yes", and 7 of them replied "no" to this question. The beneficiaries who replied "no" stated that they have quit raising livestock long ago. "Are you raising livestock now?" 2 of the beneficiaries replied "yes", and 33 of them replied "no" to this question. 26 beneficiaries who were interviewed stated that they have sold their animals before they were relocated as there were no cattle sheds in their new lots. 1 beneficiary has stated that he has built a small cattle shed in his lot and that he moved to his new house after selling most of his animals. Another beneficiary who continues to raise livestock has stated the following:

"I had about 60 sheep and goats and 4 cows. I could not move here for 1.5 years after the construction was completed because there were no cattle shed. We built a cattle shed about 5-6 miles away from the village and moved into our new house after we have moved our animals there."

Another beneficiary who has moved to his new house 15 days ago said:

"I could not move this house for a long time as I could not leave my animals. We sold our animals because we had to move."

Beneficiaries were asked about the physical characteristics of their previous houses. All the beneficiaries who were interviewed stated that their previous houses had 2 floors, the lower floor had a cattle shed, a woodshed and a bakery, and the upper floor was consisted of the living spaces.

Beneficiaries were asked to compare their previous houses with their current houses, and their previous lots and current lots in terms of size. Participants compared the size of the upper floor of the previous house, where the living quarters were available, with the size of their current houses.

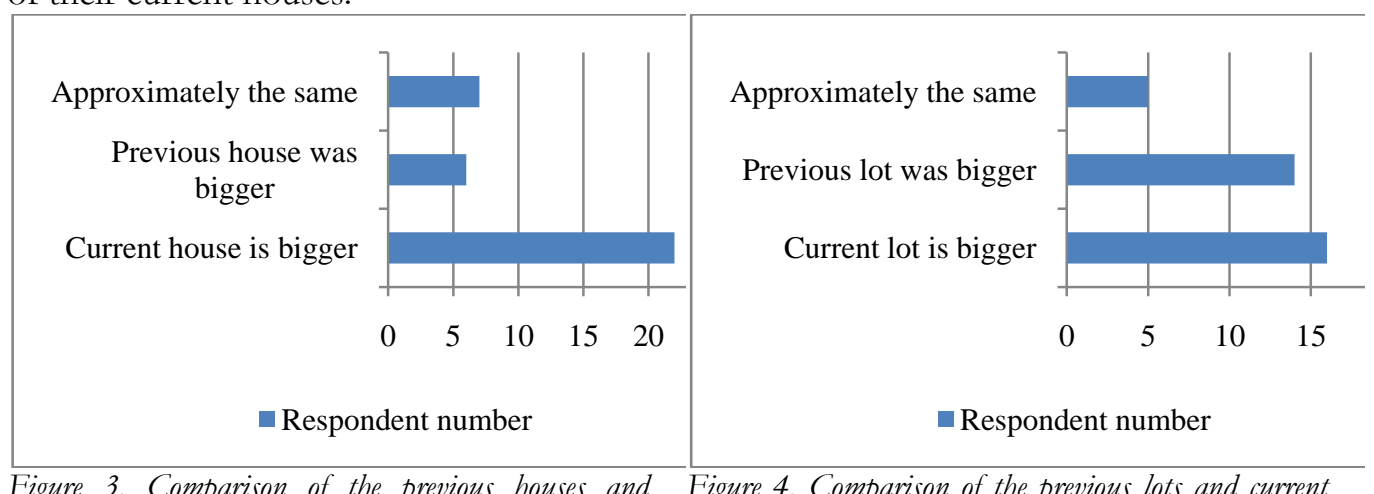

Figure 3. Comparison of the previous houses and Figure 4. Comparison of the previous lots and current current houses of the beneficiaries in terms of size lots of the beneficiaries in terms of size 
The responses taken from the participants are shown in Figures 3 and 4. It is observed that the majority of the beneficiaries have bigger houses than their previous houses with the relocation project. It can be said that approximately half of the beneficiaries participating in the survey previously had bigger lots compared their current lots, and the other half has bigger lots at present compared to the previous ones.

Respondents had the option to give more than one answers to the questions regarding what they like and complain most about their houses and the type of modifications they have made. Residents were asked what they like most about their new houses. Answers given by the participants were: "the materials used", the fact that "WC is inside the house", that the house is "easy to clean", is "big" and is "new". The numerical distribution of these answers is shown in Figure 5. The beneficiaries stated that their previous houses were the old buildings built with local materials and that the WC was out of the house, and that they were very pleased to be relocated to a new house built with modern materials.

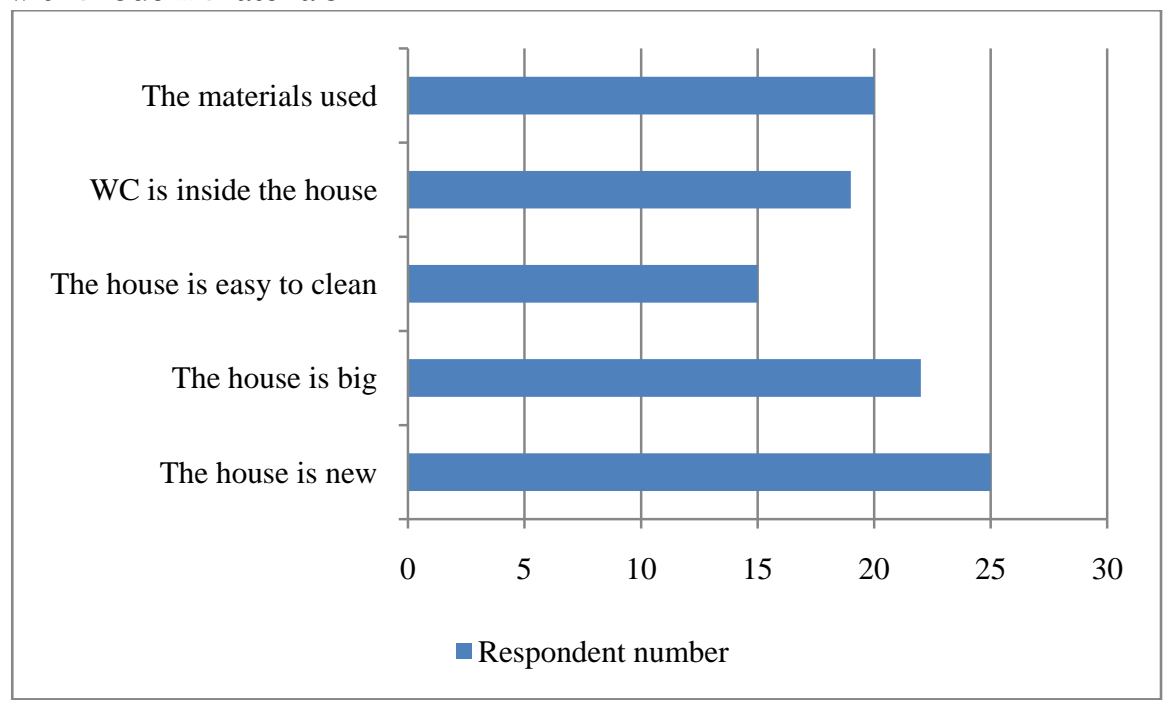

Figure 5. Participants' most favourite features about their houses

Residents were asked about what they complain most about their houses. Answers given by the participants were: "water ingress from the frames", "falling off plasters", the fact that "no cattle sheds are available", "no woodsheds are available", "no bakeries are available" and that the "lot is small" (Figure 6). Most of the beneficiaries have replaced their doors and windows, but they stated that they had suffered a lot due to the water ingress problem before this replacement. Residents who heat their houses with heating stoves and who use firewood for fuel complain about the fact that they have no space to store their firewood. The villagers bake their breads themselves and required a baking area. Participants complained that their new houses did not have cattle sheds, woodsheds, and bakeries, and that their lots did not have the adequate size to build such service units. 


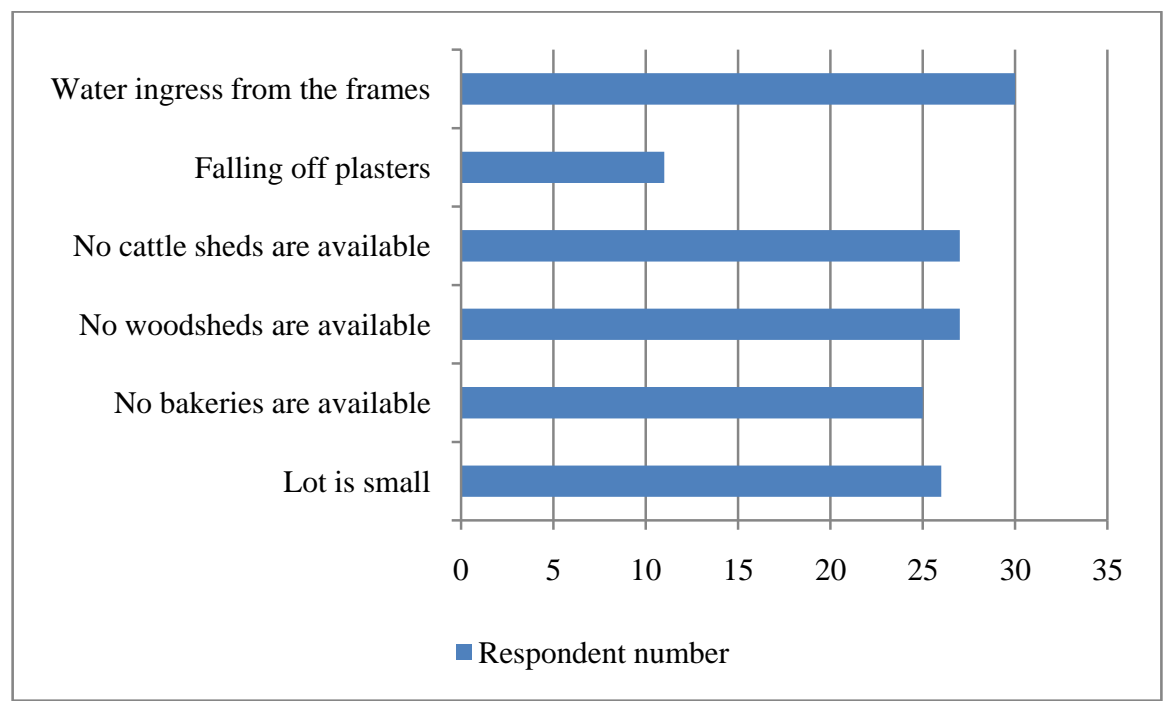

Figure 6. The characteristics of the houses that the participants complain most about

"Have you made any change on your house?" 33 of the participants replied "yes", and 2 of them replied "no" to this question. Participants were asked what kind of changes they have made in their houses. None of the beneficiaries interviewed made a change related with the plan of their houses, such as removing a wall or adding a wall. Changes such as replacement of doors and windows, building a lean-to-roof, a terrace, a cattle shed, an entrance unit, a bakery and woodshed and adding windows were made in the buildings. The numerical distribution of the changes made in the houses is shown in Figure 7.

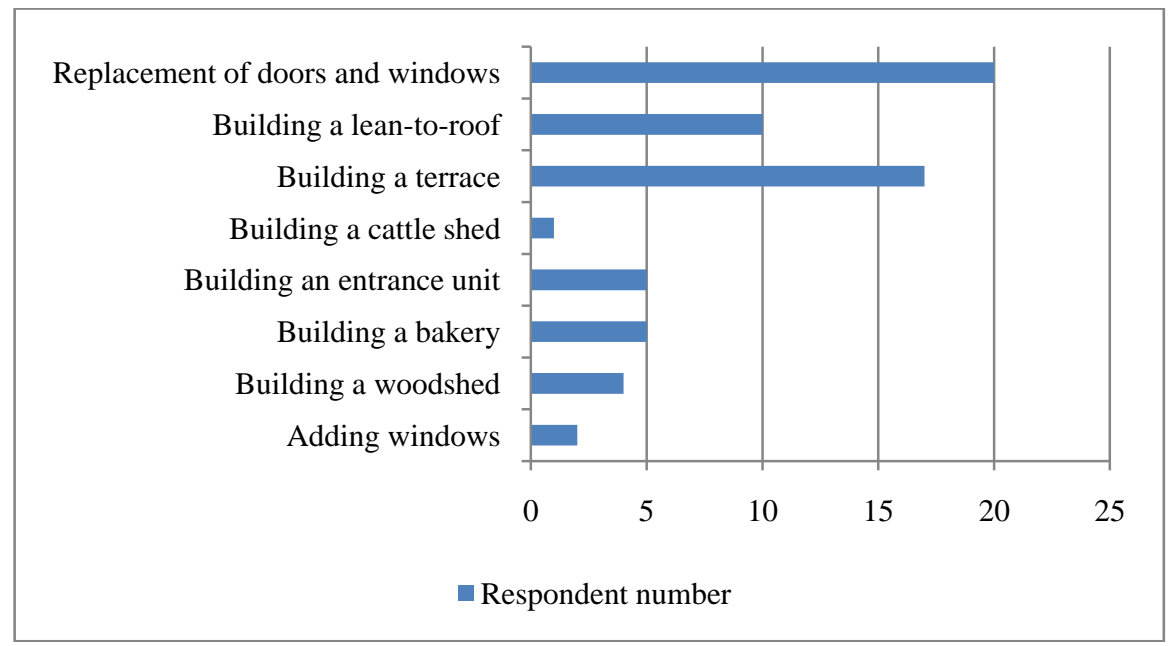

Figure 7. Changes made by the residents in their houses

In addition to spending time with their neighbours, villagers also require an open space connected to their houses to prepare food for winter. The $3.13 \mathrm{~m}^{2}$ terrace at the entrance 
of the house is inadequate for such activities. Although they prefer a closed space as a bakery, some residents have enlarged their terraces and built a lean-to-roof to create a space for baking bread. Some residents have added a closed unit to be used as a cloakroom and woodshed to the entrance of their houses. Figures 8, 9, 10 and 11 show houses changed by their residents.

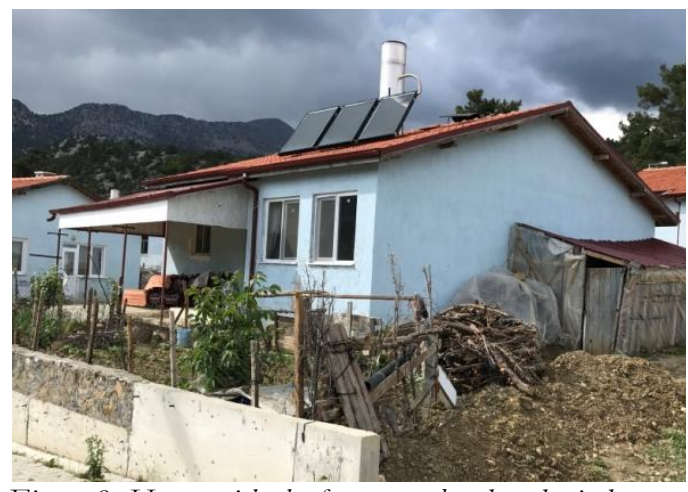

Figure 8. House with the frames replaced and window, terrace, lean-to-roof and woodshed added

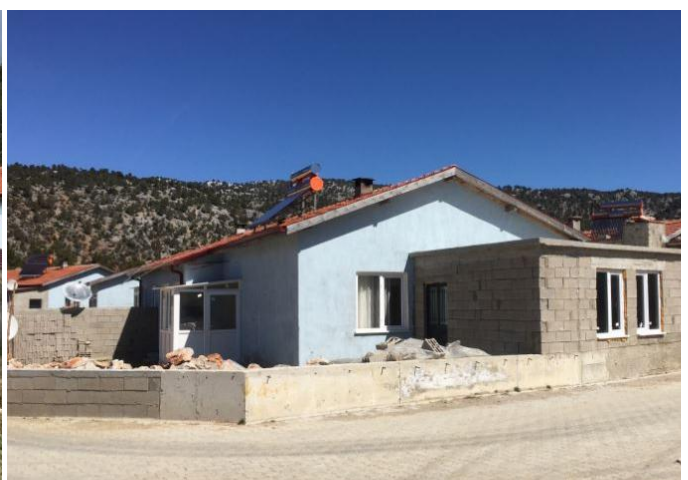

Figure 9. House with the frames replaced and an entrance unit and bakery added

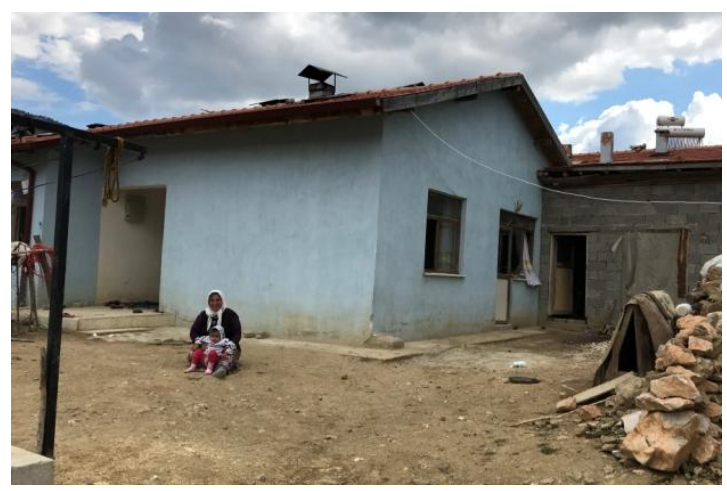

Figure 10. House with a bakery added

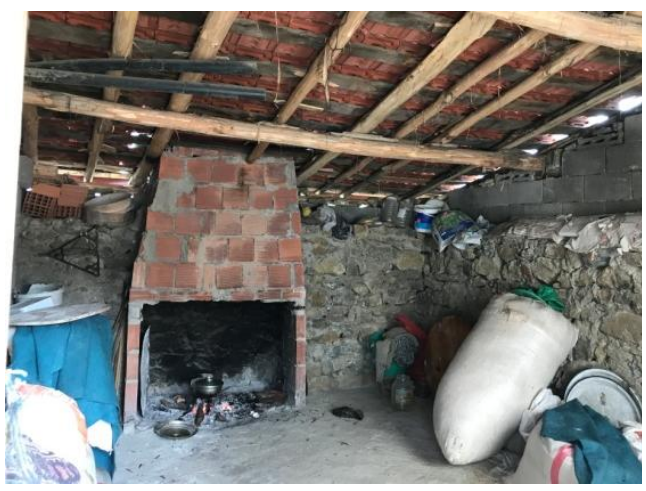

Figure 11. Inside of the bakery

Most of the beneficiaries have replaced the doors and windows of their houses due to the water ingress problem, and those who could not replace the frames as a result of financial problems have tried to solve this problem by covering the doors and windows with nylon (Figure 12). 


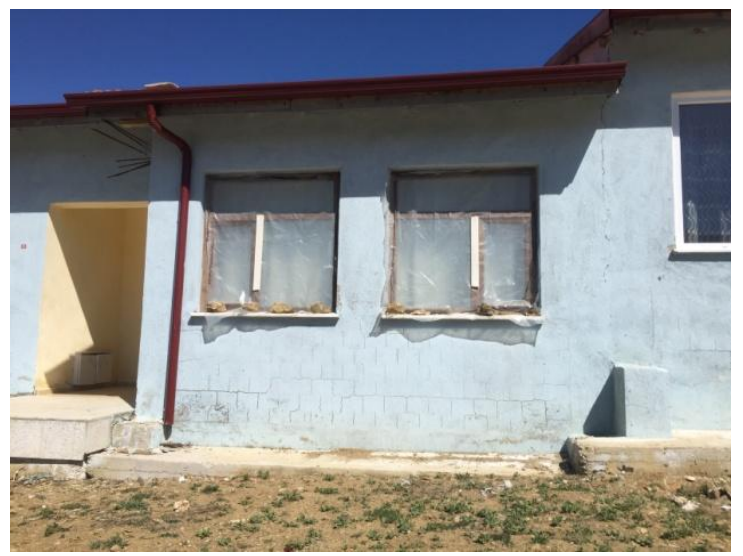

Figure 12. Measures taken by the residents in the windows against the water ingress problem

According to the data obtained in the survey, there have been some changes in the living conditions of the beneficiaries as a result of the relocation project. Some of these changes are positive and others are negative. Positive changes in the living conditions of the beneficiaries may be listed as:

- The fact that they have been relocated to a safe area in terms of disaster,

- That they have started to live in houses built with modern building materials, and

- That they have larger houses.

And negative changes that have occurred in the living conditions of the beneficiaries are:

- The fact that they had to quit raising livestock as there are no cattle sheds,

- That their daily living activities are interrupted due to the lack of the service units required,

- $\quad$ That they had to spend labour and money to build some units, and

- $\quad$ That they had to cope with the problems arising from workmanship errors.

\subsection{Satisfaction Levels of the Beneficiaries with Their Houses}

The satisfaction levels of the residents with their dwelling units, lots and the settlement were examined separately.

\subsubsection{Satisfaction Levels of the Beneficiaries with Their Dwelling Units}

The satisfaction levels of the beneficiaries with their dwelling units are examined under 4 headings: size, plan, façade and construction.

Size

It is observed that the beneficiaries are quite satisfied with size and number of the rooms in their houses and with the size of their houses. As described in the previous section, many of the beneficiaries' new houses are larger than their previous houses. It may be said that having larger living areas has an effect on the fact that the residents have high satisfaction levels. The level of satisfaction with the size of the terrace is low; thus some of the residents have enlarged their terraces (Figure 13). 


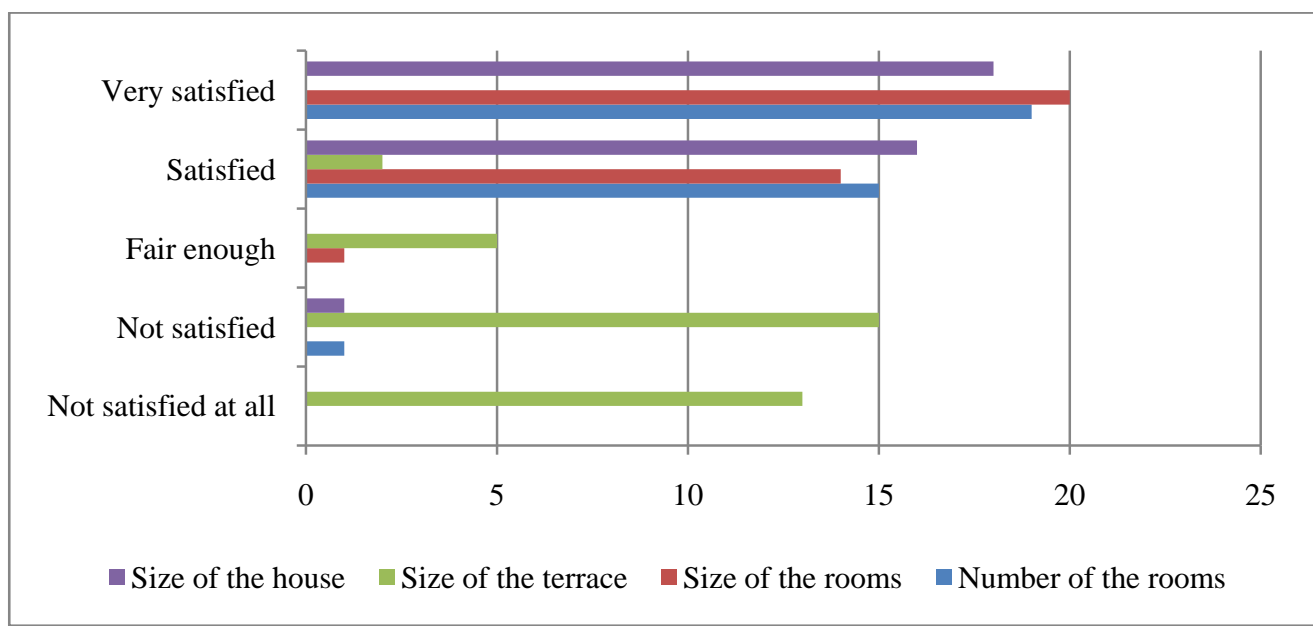

Figure 13. Satisfaction levels of the beneficiaries with the size of their houses Plan

The level of satisfaction of the beneficiaries with the plan of their houses is quite high. 18 of the participants answered as I'm very satisfied and 17 of them answered as I'm satisfied when they are asked about the location of the sitting room, the living room, the bedroom, the kitchen, the bathroom, the WC and the plan in general. It may be said that the house designed for Cukur is successful in terms of spatial organization.

Façade

Beneficiaries are satisfied with the size of the windows in their houses, but they find the number of the windows inadequate. The reason of the dissatisfaction with the number of windows is the lack of a window in one wall of the sitting room. The beneficiaries who were interviewed stated that the sitting room is not illuminated adequately. The answers given by the participants on the size and number of the windows in their houses are shown in Figure 14.

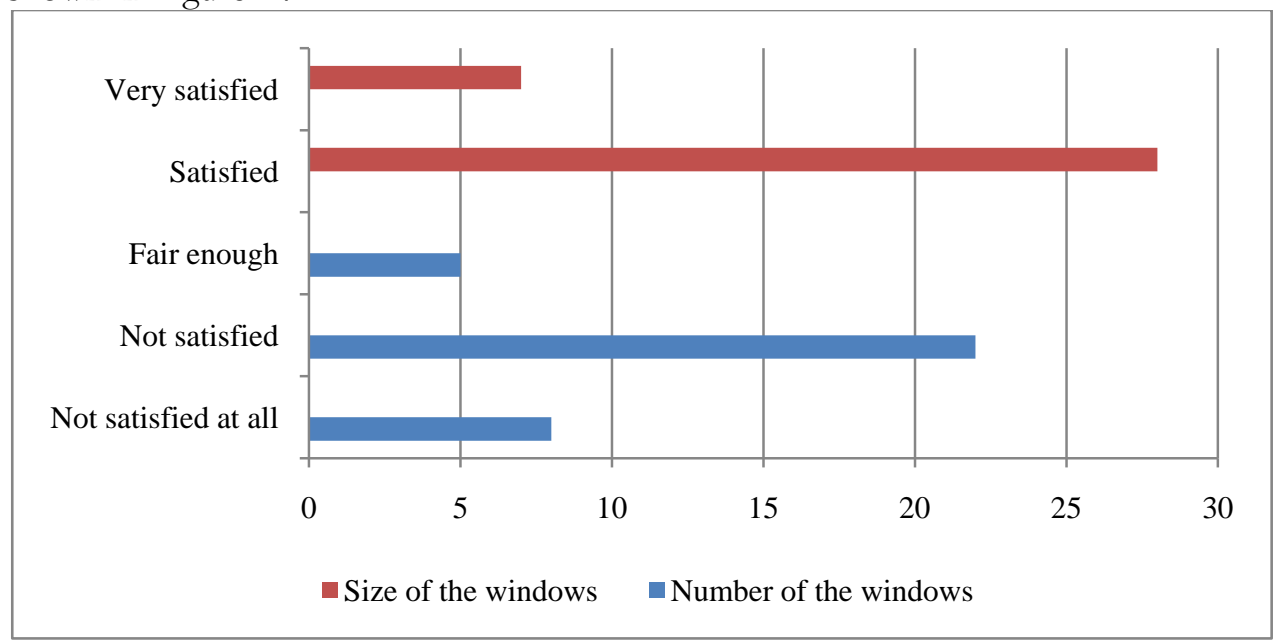

Figure 14. The answers given by the participants on the size and number of the windows in their houses 


\section{Construction}

Beneficiaries are satisfied with the building materials used in their houses. However, it is observed that the residents are not satisfied with the quality of construction. The most important reasons for dissatisfaction with the quality of the construction are the water ingress from the windows and the falling off plasters (Figure 15).

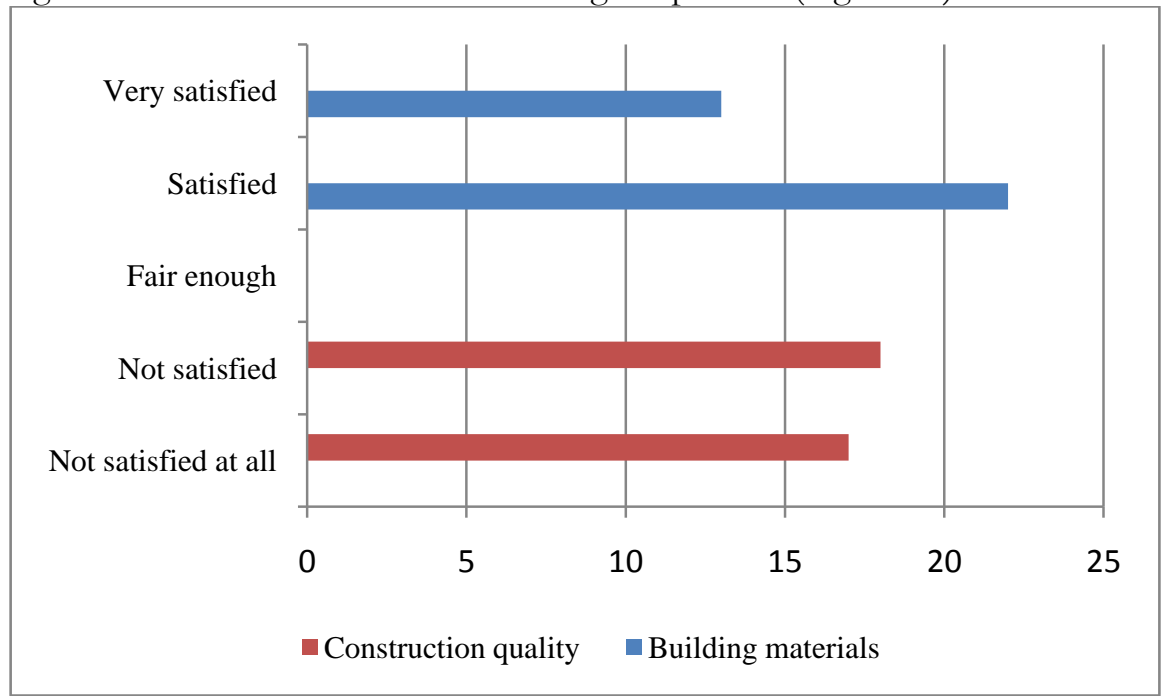

Figure 15. Assessments of the beneficiaries about their houses in terms of construction

\subsubsection{Satisfaction Levels of the Beneficiaries with Their Lots}

Residents complain that they did not have adequate space to build cattle sheds, woodsheds, and bakeries in their lots. Thus, the level of satisfaction with the size of the lots is low. According to the data obtained in the first section of the survey, approximately half of the beneficiaries interviewed lived in houses built in smaller lots in their old settlement, and the service units they required were on the ground floor of their two-storey houses. In the new settlement, they require larger lots to build service units as they have single-storey houses which consist of living units only. The satisfaction level of the residents with the layout plan is also low. The reason for this is the noise problem caused by the fact that the houses are built as attached to each other. Beneficiaries prefer to live in independently constructed houses (Figure 16). 


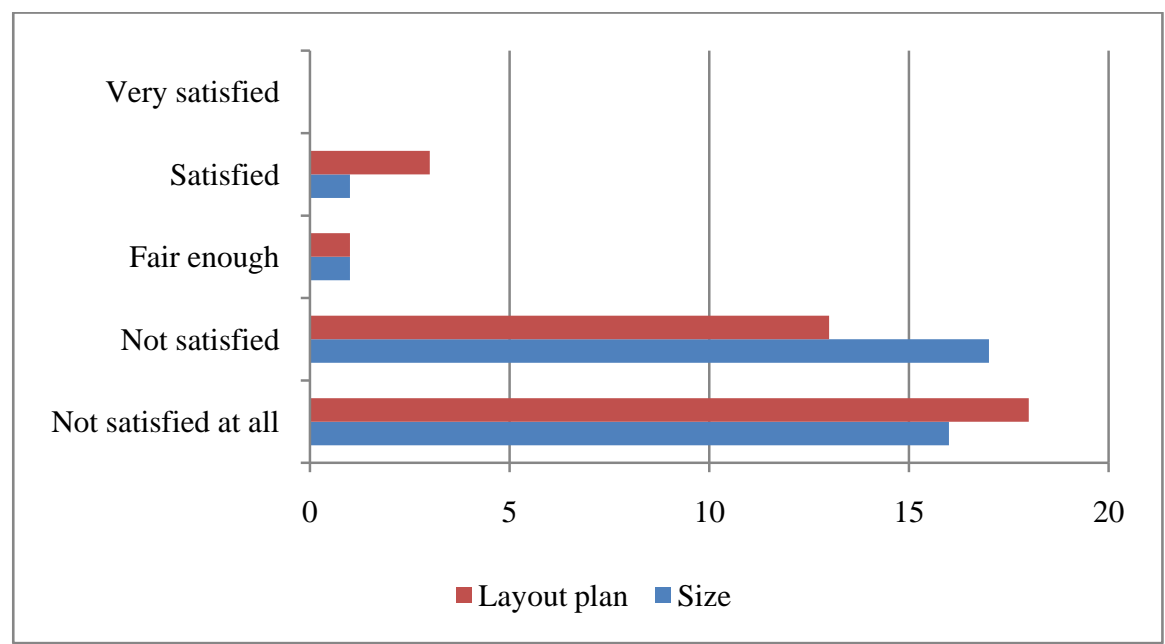

Figure 16. Satisfaction levels of the beneficiaries with their lots

\subsubsection{Satisfaction Levels of the Beneficiaries with the Settlement}

The satisfaction levels of participants with the settlement are shown in Figure 17. Most of the beneficiaries are satisfied with the new settlement. The closeness of the old and new settlements has allowed the beneficiaries to resume their social ties with their villages. In terms of access, some of the villagers are satisfied with their new settlements, some are neutral and some are not. The ones that are dissatisfied stated that they experienced difficulties as icing occurs on the inclined road at the entrance of the settlement during the winter months. The beneficiaries have made different assessments about the distance to their fields/gardens. Some beneficiaries stated that their old houses were closer to their fields/gardens and that they cannot access their fields/gardens as easily as it used to be from the new settlement; and some stated that they have moved away from their fields/gardens when they were relocated to the new settlement, but the difference is not much. The villagers are satisfied with the infrastructure services offered in the new settlement such as road, water and electricity.

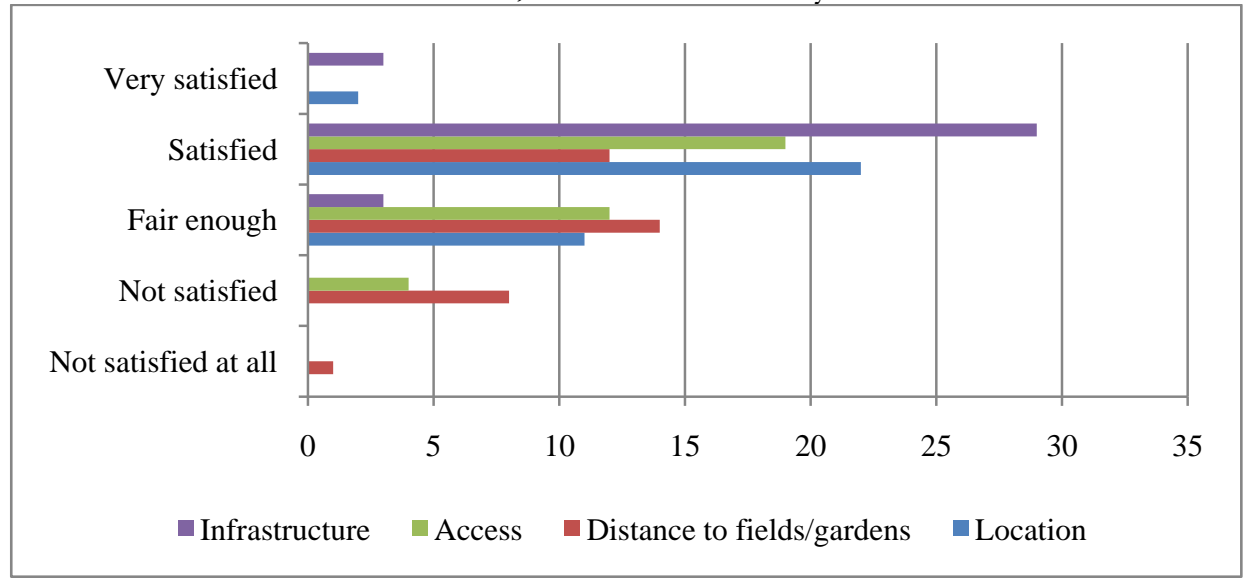

Figure 17. Satisfaction levels of the beneficiaries with the settlement 
When the cases, where the beneficiaries are satisfied with their houses, lots and their new settlement, are examined, it was determined that satisfaction occurred due to three main reasons. These are the fact that a location close to the old village has been selected, that the villagers were relocated to houses with better physical conditions than the old ones and that the infrastructure works required for basic living activities were already completed in the new settlement.

It was determined that dissatisfaction of beneficiaries with their houses, lots and their new settlement occurred due to three main reasons. These are the problems caused by workmanship errors, problems related to noise and natural lighting, and inadequacy of the spaces that allow maintaining of the daily living activities.

\section{Conclusions and Recommendations}

If there is nothing that can be done in order to prevent a disaster in a region with disaster risk, it is a right decision to relocate the settlement in order to secure life and property. The answers to the question of where and how the settlement shall be established are of great importance in such a case. The basic criterion for decisions to be made about the resettlement projects shall be to ensure a sustainable relocation that is the new living conditions of the beneficiaries are at least as good as the old conditions. There are both positive and negative aspects of the project implemented for the relocation of the area under the risk of rockfall in Cukur Village, Isparta. Positive aspects of the project are:

- Relocation of the villagers living under a disaster risk to a safe area,

- The fact that the social ties between the old settlement and the new settlement are not interrupted,

- $\quad$ The fact that the construction works were completed on time,

- That the villagers were provided with houses with better physical conditions than their old houses, and

- That the infrastructure works required for basic living activities were already completed in the new settlement.

And the negative aspects of the project may be listed as follows:

- Problems arising from the method of payment of the housing loan,

- Problems arising from workmanship errors,

- Noise and natural lighting problems,

- Interruption of daily living activities as the service spaces were not provided.

The method of payment for the housing loan shall be reviewed. Such problems shall be prevented if it is ensured that the payment is made to the contractor or the beneficiary only, provided that they comply with the relevant contracts. Placing sanctions on contractors for the problems caused by errors in the execution may be useful to avoid workmanship errors. A window to be placed on the blind wall of the sitting room shall solve the problem of natural lighting for the architectural project used in Cukur. Sound insulation shall be applied between the two buildings when it is required to build attached houses. 
In rural areas, housing is not comprised of a dwelling unit only. Service units are indispensable parts of rural houses. While the fact that larger, newer and modern houses were built on the Cukur project made it possible for the villagers to have a high level of satisfaction, the lack of service units led to negative changes in the living conditions of the beneficiaries. There are two options that may be applied to avoid similar problems in the reconstruction projects to be implemented in rural areas in the future: providing the beneficiaries two-storey houses that have service units in the ground floor and living spaces in the upper floor, or larger lots with single storey houses. Undoubtedly, both proposals shall cause an increase in costs. In the first proposal, the cost of a two-storey building shall not be increased exact double of the costs as the quality, type and amount of the materials to be used for ground floor shall differ from those that shall be used in the dwelling unit. If houses with the same area of living space as the old houses, but with two floors were built in the Cukur project, it shall be possible to resume the daily living activities of the villagers in the same way. Although the static projects of the existing houses are designed to allow building of extra floor, it is quite cumbersome and costly to construct living areas on the upper floor and transforming the lower floor to service spaces.

In the second proposal, the beneficiaries shall have to spend labour, time and money to build additional units beside the increased land costs. It is also very difficult to find lots in rural areas that do not have a disaster risk, that are not already fields/garden areas, which are close to the old settlement and at the same time that offer adequate size for resettlement projects. For these reasons, it shall be more appropriate to implement the first proposal in order to resolve the troubles that have been experienced.

\section{References}

[7]. M. Abe and R. Shaw, in: Rajib Shaw (Eds.), Critical factors for sustainable post-tsunami resettlement: cases from India and Sri Lanka in Recovery from the Indian Ocean tsunami: a ten-year journey, Springer, Tokyo, 2014.

[1]. H. Baytiyeh, Socio-cultural characteristics: the missing factor in disaster risk reduction strategy in sectarian divided societies, International Journal of Disaster Risk Reduction 21 (2017) 63-69.

[13]. X. (J.) Cao and D. Wang, Environmental correlates of residential satisfaction: an exploration of mismatched neighbourhood characteristics in the Twin Cities, Landscape and Urban Planning 150 (2016) 26-35.

[2]. P. Claudianos, Out of harm's way; preventive resettlement of at risk informal settlers in highly disaster prone areas, Procedia Economics and Finance 18 (2014) 312-319.

[9]. L. Chen, W. Zhang, Y. Yang and J. Yu, Disparities in residential environment and satisfaction among urban residents in Dalian, China, Habitat International 40 (2013) 100-108.

[5]. E. Correa, F. Ramirez, H. Sanahuja, Populations at risk of Disaster: A resettlement guide, The World Bank, Washington, 2011.

[20]. K. Dekker, S. de Vos, S. Musterd and R. van Kempen, Residential satisfaction in housing estates in European cities: a multi-level research approach, Housing Studies 24 (4) (2011) 479-499, http://dx.doi.org/ 10.1080/02673037.2011559751.

[22]. N. Dikmen, in: Gonzalo Lizarralde, Cassidy Johnson, Colin H. Davidson (Eds.), User requirements and responsible reconstruction in Rebuilding after disasters: from emergency to sustainability, Taylor \& Francis, London, 2009.

[24]. N. Dikmen and S. T. Elias-Ozkan, Housing after disaster: A post occupancy evaluation of a reconstruction project, International Journal of Disaster Risk Reduction 19 (2016) 167-178, http://dx.doi.org/10.1016/i.ijdrr.2016.08.020 
[8]. Y. Fang, Residential satisfaction, moving intention and moving behaviours: a study of redeveloped neighbourhoods in Inner-City Beijing, Housing Studies 21 (5) (2006) 671-694, http://dx.doi.org/10.1080/02673030600807217.

[23]. R. Gunay, Tradition of the Turkish House and Safranbolu Houses, İstanbul: Güzel Sanatlar Matbaaası A.Ş., 1998.

[11]. Z. Huang, X. Du and X. Yu, Home ownership and residential satisfaction: evidence from Hangzhou, China, Habitat International 49 (2015) 74-83.

[18]. E. O. Ibem, A. P. Opoko, A. B. Adeboye, D. Amole, Performance evaluation of residential buildings in public housing estates in Ogun State, Nigeria: users' satisfaction perspective, Frontiers of Architectural Research 2 (2013) 178-190.

[4]. T. Jamieson, Disastrous measures: conceptualizing and measuring disaster risk reduction, International Journal of Disaster Risk Reduction 19 (2016) 399-412.

[16]. S.J.T. Jansen, The impact of the have-want discrepancy on residential satisfaction, Journal of Environmental Psychology 40 (2014) 26-38.

[19]. A. D. Jiyobe, Post-occupancy evaluation of residential satisfaction in Lagos, Nigeria: feedback for residential improvement, Frontiers of Architectural Research 1 (2012) 236-243.

[6]. D. King, D. Bird, K. Haynes, H. Boon, A. Cottrel, J. Millar, T. Okada, P. Box, D. Keogh, M. Thomas, Voluntary relocation as an adaptaion stategy to extreme weather events, Journal of Disaster Risk Reduction 8 (2014) 83-90.

[15]. Z. Li and F. Wu, Residential satisfaction in China's informal settlements: a case study of Beijing, Shanghai, and Guangzhou, Urban Geography 34 (7) (2013) 923-949, http://dx.doi.org/10.1080/02723638.2013.778694.

[12]. M. Lu, Determinants of residential satisfaction: ordered logit vs. regression models, Growth and Change a Journal of Urban and Regional Policy 30 (2) 1999 264-287, http://dx.doi.org/10.1111/0017-4815.00113.

[3]. A. Oliver-Smith, The social construction of disaster risk: seeking root causes, International Journal of Disaster Risk Reduction (2016), http://dx.doi.org/10.1016/j.ijdrr.2016.10.006

[14]. A. Parkes, A. Kearns and R. Atkinson, What makes people dissatisfied with their neighbourhoods?, Urban Studies 39 (13) (2002) 2413-2438.

[17]. O. M. Ukoha, J. O. Beamish, Assessment of residents' satisfaction with public housing in Abuja, Nigeria, Habitat International 21(4) (1997) 445-460.

[10]. D. Wang and F. Wang, Contributions of the usage and affective experience of the residential environment to residential satisfaction, Housing Studies 31 (1) (2016) 42-60, http://dx.doi.org/10.1080/02673037.2015.1025372.

[21]. R. Zetter and C. Boano, Gonzalo Lizarralde, Cassidy Johnson, Colin H. Davidson (Eds.), Space and place after natural disasters and forced displacement in Rebuilding after disasters: from emergency to sustainability, Taylor \& Francis, London, 2009. 